\title{
Arylamine N-Acetyltransferase 2
}

National Cancer Institute

\section{Source}

National Cancer Institute. Arylamine N-Acetyltransferase 2. NCI Thesaurus. Code

C17773.

Arylamine N-acetyltransferase $2(290 \mathrm{aa}, \sim 34 \mathrm{kDa})$ is encoded by the human NAT2 gene.

This protein plays a role in xenobiotic metabolism. 